\title{
The New Italian Legislation on Corporate Governance and Business Crisis. The Impact of COVID - 19 on SMEs and the Recent Rules to Mitigate the Effects
}

\author{
http://doi.org/10.21272/fmir.4(4).91-108.2020
}

Francesco Di Tommaso

Account Manager and PhD Economics and Finance, University of Rome La Sapeinza, Italy

\begin{abstract}
The economic challenges of recent years have been accompanied by numerous and complex economic and social crises, the last of which is caused by the spread of coronavirus COVID-19 - and is convergent in nature, the effects of which are felt in all spheres of society. The COVID-19 pandemic poses serious challenges for politicians and preconditions for an empirical analysis of the direct and indirect consequences of the pandemic for the development of the global economy. As part of the business crisis, Italian legislation is based on the principles of the 2019 EU legal framework, which include legal regulation for the management of economic entities, which allows to anticipate the business crisis, avoiding bankruptcy and improving the market. Legal regulation of the financial crisis contributes to the preservation of production capacity and employment, reduces the possibility of creating non-performing loans, which can negatively affect the balance sheets of banking institutions. A study by the Bank of Italy demonstrates the possibilities of avoiding insolvency if companies anticipate a business crisis by following bankruptcy deflation procedures, such as debt restructuring agreements and agreements with creditors. COVID-19 has led to a significant reduction in world GDP. Governments have different financial means to reduce the negative effects of the pandemic, but all consider the current economic moment exceptional, trying to postpone and mitigate the implementation of bankruptcy of many companies and enterprises in case of failure of legal systems. The results of the study show that the global recession will continue, and no country will avoid strengthening the legal regulation of administrative and accounting management, regardless of the strategy to mitigate the effects of the pandemic. The paper forms the opinion that today's events require a coordinated multinational political response to the pandemic.
\end{abstract}

Keywords: corporate governance, financial markets.

JEL Classification: G280.

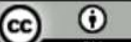

Cite as: Tommaso, F. D. (2020). The New Italian Legislation on Corporate Governance and Business Crisis. The Impact of Covid - 19 on SMEs and the Recent Rules to Mitigate the Effects. Financial Markets, Institutions and Risks, 4(4), 91-108. http://doi.org/10.21272/fmir.4(4).91-108.2020.

\section{Introduction}

The economic context is increasingly complex and in recent decades we have had many crises, the last and most important is the one generated by the spread of the coronavirus - COVID-19, international legislators have introduced regulations that create a harmonious context, to protect the market and competition, the crisis that companies have to face due to the variability of economic conditions by introducing bankruptcy rules that tend to anticipate the emergence of financial difficulties, thus preserving the level of production and employment and avoiding situations of irreversible insolvency. COVID-19 has led to a strong contraction in world GDP and by reducing production activities and consumption is causing several failures.

Countries are dealing with the economic problems caused by the pandemic in a different way, but all are concerned about considering the current economic moment exceptional by trying to postpone and mitigate the application of the rules on the failure of their legal systems.

In this paper, the recent legislation on the business crisis introduced in Italy and its important effect on governance and organizational structures will be examined and finally the interventions of the Italian legislator who during the last months have provided simplifications and facilitations aimed at guaranteeing and preserving business continuity of companies affected by the current economic slowdown. 


\section{The Regulatory Reform introduced in Italy with Legislative Decree 14 of 2019}

The Legislative Decree number 14 of 12 January 2019 issued in implementation of the delegated law of 19 October 2017, n. 155 and published in the G.U. 38 of 14 February 2019 - s.o. n. 6 - entered into force on 16 March 2019, modifying article 2477 of the civil code and extending the obligation to appoint the supervisory body - the board of statutory auditors or the statutory auditor - both for liability companies limited that, through the reference to article 2543 of the civil code, to cooperatives. The reform is the result of a long and troubled work that has ancient roots if we think that already in the early years of the new millennium the legislator was aware of having to modernize the legal system of the Royal Decree of 1942; in fact, the Trevisanato commission was established, by decree of the Minister of Justice of 28 November 2001, which reads: "for the elaboration of guiding principles and criteria of a draft law delegated to the Government, relating to the of the new bankruptcy law and the revision of the rules concerning related institutions". The commission, which had already thought of the alert systems that characterize the current discipline, was unable to reach a shared document due to internal conflicts. Subsequently, in 2005, the Executive fired the Decree Law no. 35 of 14 March 2005, introducing provisions of absolute importance in the insolvency regulations then in force. The changes affected the revocation institution, within which, albeit unhappily due to legislative technique, the attested plans, debt restructuring agreements and not least the arrangement with creditors found space. Further changes were made with the entry into force of the Legislative Decree of January 9, 2006, no. 5, which implemented the delegation conferred by the law converting the D.L. 35/2005 number 80 of 14 May 2005. Other changes followed, including those introduced by the Legislative Decree of 12 September $2007 \mathrm{n} .169$ which touched on the arrangement with creditors and the provisions of Article 1 of the bankruptcy law on companies subject to bankruptcy. Then still other interventions: first with the decree law of 31 May 2010, $\mathrm{n}$. 78 (converted with amendments by law no.122 of 30 July 2010) with changes in the area of pre-deductibility of credits both for the arrangement with creditors and for debt restructuring agreements and, finally, with the law of 27 January 2012, no. . 377 through which the legislator has provided for a specific procedure that was to settle the crises following over-indebtedness aimed at entrepreneurs who could not, pursuant to article 1 of the LF, apply the provisions on insolvency procedures. This itinerary, so to speak, started with the decree law number 35 of 14 March 2005 and continued with the aforementioned rules and others, has substantially pushed the bankruptcy legislation in two directions: on the one hand towards the introduction of the "deflationary" institutes of insolvency of the company and on the other hand pushing on the contractual and private solution of the crisis, always in the hope of being able to avoid bankruptcy through greater protection of business continuity. Last but not least, the intervention envisaged with the issuance of the decree law of 27 June 2015, no. 85 (converted with amendments by law no.132 of 6 August 2015), through which the government has introduced minimum satisfaction percentages for unsecured creditors, in the liquidation arrangement procedure, equal to at least $20 \%$, in order to avoid abuses of entrepreneurs in difficulty to the detriment of the position of non-privileged individuals. Thus, we come to the present day and the delegation provided for by Law no. 155 of 19 October 2017 which led us to the issuance of Legislative Decree no. 14/2019 in comment. The reform is also partly inspired by European legislation, by Community Regulation no. 848 of May 20, 2015 and by Recommendation 135 of 2014. The economic crisis has marked the entrepreneurial fabric of the European economic union and has put in crisis the banks that have seen their bad debts grow (the so-called "NPL" non-performing loans).

It is for this reason that in Europe there has been attention to rationalize and harmonize the law of the business crisis and so it was recently approved and published in the Official Gazette. of the European Union on 26 June 2019, the EU Directive number 1023 of 20/6/2019 through which the European Parliament reviews the rules governing preventive restructuring of companies, not neglecting to define debt relief and suitable measures to improve insolvency proceedings. The new directive amends the previous directive 2017/1132. Member countries have until July 17, 2021 to implement it. Our executive will therefore have to integrate and modify the Legislative Decree no. 14/2019. The new Crisis Code is already, to a large extent, in line with EU principles. Probably, between now and August 2021, changes could be introduced that make the new regulatory framework compliant with EU principles. The deadline for entry into force of the Corporate Crisis Code provided for in paragraph 1 of art. 389 of the aforementioned legislative decree provided for the entry into force of the rules as of August 15, 2020, with the exception of the provisions in force since March 16, 2019 in the area of corporate law and above all valid organizational structures. The Liquidity Decree converted into Law 5 June 2020, n. 40 postponed the entry into force of the Corporate Crisis Code, bringing it to September 1, 2021. In the first place, the merit of the new Code of business crisis and insolvency (hereinafter 
CCII) was to clarify the concept of "business crisis". The old legislation had not defined it, the only exceptions were due to the fact that this concept recurred with regard to the arrangement with creditors, in which it was established that the debtor in a state of "crisis" could make use of it and, finally, the term crisis was already present since 1979 in the law establishing extraordinary administration, which referred to «large companies in crisis. The CCII defines the crisis as the condition that makes insolvency probable: a prognostic state, caused by financial and economic imbalances (Art. 2 letter a). There is no reference to equity imbalances, because, incorrectly, it is believed that the patrimonial crisis is only the one that derives from negative equity (total liabilities greater than total assets). While, on the other hand, companies may have an economic crisis that, for example, reduces operating income, reduces self-financing and therefore reduces cash, creating the need for the ignition to have new loans, which create a growth in means. of third parties (and the one described is clearly a capital imbalance). In fact, in line with what is said in Article 13, the first paragraph reads: "Imbalances of an income, equity or financial nature constitute crisis indicators". Another merit of the reform is to have introduced tools that lead to the early emergence of the business crisis in order to avoid the deterioration of the economic and patrimonial situation and the consequent bankruptcy; this new tool consists of the alert mechanism. The alert is the institution that leads some subjects to report a possible business crisis if the limits or certain thresholds that indicate a state of potential crisis should emerge; for reports made by internal bodies (statutory auditors or auditors even if the auditor is not part of the corporate bodies) we will have an internal alert; if the report is made by the Revenue Agency, by INPS or by the Collection Agent, we will have an external alert. The alert is therefore a communication addressed to the administrative body (internal alert) or to the debtor (external alert) which warns of a possible crisis of the company which has obviously intercepted some of the indicators required by law.

\section{Internal alert}

When the crisis results from certain indicators, the control body or the auditor must formally report the elements detected to the administrators, assigning them a period of 30 days to report on the solutions identified and the initiatives taken. In the event of an inadequate response or failure to take the necessary measures within the next 60 days, the mayor or auditor must immediately inform the OCRI (body responsible for the composition of the business crisis) providing all useful elements.

\section{External Alert}

The Revenue Agency, the National Institute of Social Security and the Collection Agent have the obligation, for the first two subjects under penalty of ineffectiveness of the right of pre-emption due on the credits they hold, for the third one under penalty of non-enforceability of the credit for collection expenses and charges, to report to the debtor the existence of debts beyond the thresholds described in the previous chapter; the reported person will have 90 days to pay or activate the procedures for resolving the crisis or insolvency; in the absence of a response, the creditor will report to the OCRI. The reporting to the OCRI is not carried out if the debtor documents that he is the holder of receivables from the PA for an amount greater than half of his debt (a professional certification is required).

\section{Possible outcomes of the procedure}

Following an alert there are two situations:

1) The administrative body replies that it will take appropriate actions to define the crisis: the person who reported then verifies that the procedures have been undertaken or, for example, verifies that the debt to the public administration has been paid and the alert closes;

2) The administrative body does not respond or does so in an unsatisfactory way: the report to the OCRI is then opened. Three professionals are appointed here, and the debtor is summoned and asked to report within 15 days (for smaller companies, the procedure will be summarized in the OCC body for the settlement of the over-indebtedness crisis).

The board of three professionals must:

a) schedule the hearing of the debtor within 15 days;

b) also convene the control body or the auditor;

c) work while maintaining absolute confidentiality of the file;

d) file if there are no well-founded indications of a crisis. 
The assisted settlement procedure can also be activated at the request of the debtor.

If, on the other hand, the college deems the crisis to exist and the debtor does not intend to resolve it by submitting another request for access to the procedures (certified plan, restructuring agreement, composition agreement), assisted negotiation opens before the OCRI.

In this case, the body collaborates with the debtor in identifying the appropriate measures to remove the difficult situation. For example, by renegotiating debts with a partial reduction or by extending the payment terms. As soon as possible, the college acquires from the debtor, or upon his request, an updated report on the patrimonial, economic and financial situation of the company, as well as a list of creditors and holders of real or personal rights, with an indication of the respective credits and any causes of pre-emption.

It sets a deadline for the implementation of the crisis resolution measures, which can be three months, extendable for another three months, and instructs the panel's rapporteur, made up of three components, to follow the negotiations.

The agreement reached here, very similar to a certified plan, must be in writing and can be registered at the request of the debtor in the commercial register. Once the implementation and resolution of the crisis has been verified, the alert procedure is closed.

\section{The Regulatory Reform introduced in Italy with Legislative Decree 14 of 2019}

Another very important change introduced by the 2019 reform concerns the introduction into the civil code, in particular in article 2086, of the second paragraph, which reads as follows:

"The entrepreneur, who operates in a corporate or collective form, has the duty to establish an organizational, administrative and accounting structure adequate to the nature and size of the company, also in function of the timely detection of the crisis of the company and of the loss of business continuity, as well as to take immediate action for the adoption and implementation of one of the tools provided for by the law for overcoming the crisis and recovering business continuity. "

The use of the term "also" which has been placed in bold is very important; because the entrepreneur will have to establish organizational structures (already provided for spa by article 2381 of the civil code) not only to address the business crisis in a timely manner but generally to create more managerial management models.

The last part of the revised art. 2086 attaches importance to the recovery of business continuity. The principle of continuity can be found in the provisions of Article 2423-bis of the Italian Civil Code where it is envisaged that the evaluation of the balance sheet items must be made "with a view to the continuation of business activity". In this sense, OIC 11 specifies that: "when preparing the financial statements, management must prospectively assess the existence of the principle of continuity for a period of at least 12 months from the reporting date; if uncertainties were to be found from this assessment, information must be given in the explanatory notes, explaining whether the situations can be considered significant ".

On the subject, the Court of Milan, Business Section, with decree 1096 of 19/4/2016, provides that "the existence or not of business continuity and in particular the ability of the company to carry out its activities to their liabilities during the normal course of business, first of all presupposes a prognostic judgment based on two elements which in turn constitute judgments:

1) the recognition of one or more elements (for example among those indicated in paragraph A.2 of the auditing standard 570) assumed as potentially indicative;

2) the existence and credibility of a plan approved by the directors to adequately address the above elements and resolve or neutralize them definitively or for a significant period of time (generally at least 12 months)".

The organizational, administrative and accounting structures of Article 2086 of the Italian Civil Code

Organizational structures: The set of directives and procedures established to ensure that decision-making power is assigned and effectively exercised at an appropriate level of competence and responsibility (Rules of conduct of the Board of Statutory Auditors 3.4). The management and functional plans of human resources are certainly organizational structures.

Administrative and accounting structure: The set of directives, procedures and operational practices aimed at ensuring the completeness, correctness and timeliness of a reliable corporate disclosure compliant with the 
accounting principles adopted by the company (Standard of conduct of the Board of Statutory Auditors 3.6). Information and management control systems.

Internal control and risk management system: the set of rules, procedures and organizational structures aimed at allowing the identification, measurement, management and monitoring of the main risks and to ensure the company reasonable certainty of achieve its objectives (Borsa Italiana Corporate Governance Code); for example ERM enterprise risk management systems.

To comply with these precepts, the administrative body must establish an adequate organizational, administrative and accounting structure also suitable for the purpose of bringing out the crisis and the loss of continuity; and must take action without delay for the adoption and implementation of one of the instruments envisaged by the law for overcoming the crisis and recovering business continuity; pushing the company to a managerial management that leads to the control of costs, financial flows and business risks.

The control body or the auditor, within the scope of their functions, are obliged to verify that the administrative body constantly evaluates, by taking the consequent suitable initiatives, whether the organizational structure of the company is adequate, if the economic and financial balance and what is the foreseeable trend of operations, as well as to immediately report to the same administrative body the existence of well-founded indications of the crisis.

The organizational, administrative and accounting structure will be adequate when:

1) There is a clear identification of the functions, duties and lines of responsibility;

2) The decision-making activity is carried out by the resources entrusted with the decision-making power;

1) 3 Company procedures are formalized and effectively disseminated at all levels;

3) The information and financial reporting systems are adequate;

4) The integrity of the company assets is ensured.

The CCII requires the start of a business managerial process, which involves:

$>$ the procedure of activities,

$>$ the precise identification of tasks, duties and responsibilities,

$>$ the adoption of management control tools capable of acting as a decision-making compass for entrepreneurs.

As already mentioned by many, what the legislator demands is an important cultural change for businesses. The other changes concern the inclusion in the various articles of the precepts of article 2086, let's see how:

a) in article 2257 of the civil code (partnerships), the first paragraph is replaced by the following: who carry out the operations necessary for the implementation of the corporate purpose. Unless otherwise agreed, the administration of the company is the responsibility of each of the shareholders severally from the others.

b) in article 2380-bis of the Italian civil code (spa), the first paragraph is replaced by the following: who carry out the operations necessary for the implementation of the corporate purpose ".

c) in Article 2409-novies I paragraph of the Italian Civil Code (dualistic spa), the first sentence is replaced by the following: "The management of the business is carried out in compliance with the provisions of Article 2086, second paragraph, and is the sole responsibility of the management board, which carries out the operations necessary for the implementation of the corporate purpose".

d) in Article 2475 of the Italian Civil Code (srl), the first paragraph is replaced by the following: "The management of the company is carried out in compliance with the provisions of Article 2086, second paragraph and is the sole responsibility of the directors who carry out the operations necessary for the implementation of the corporate purpose".

e) in Article 2476 of the Italian Civil Code, the following is added after the fifth paragraph: "Directors are liable to corporate creditors for non-compliance with the obligations inherent in the preservation of the integrity of the corporate assets. The action can be proposed by creditors when the corporate assets are insufficient to satisfy their credits. The waiver of the action by the company does not prevent the exercise of the action by the corporate creditors. The transaction can be challenged by the corporate creditors only with the revocatory 
action when the extremes occur. In this case, the dilemma on the applicability of art. 2394 to srl. The action can be carried out within five years that run from when the harmful event occurs.

f) to article 2486 of the civil code, the following is added after the second paragraph: "When the liability of the directors is ascertained in accordance with this article, and subject to proof of a different amount, the compensable damage is presumed to be equal to the difference between the net on the date on which the director resigned from office or, in the case of opening of an insolvency procedure, on the date of opening of such procedure and the net equity determined on the date on which there was a cause for dissolution referred to in article 2484, after deducting the costs incurred and to be incurred, according to a criterion of normality, after the occurrence of the cause of dissolution and until the completion of the liquidation. If an insolvency procedure has been opened and the accounting records are missing or if due to their irregularity or for other reasons the net assets cannot be determined, the damage is liquidated to an extent equal to the difference between assets and liabilities ascertained in the procedure".

g) with regard to shareholder loans: in article 2467, first paragraph, of the civil code, the words" and, if this occurred in the year preceding the declaration of bankruptcy of the company, must be returned."

On the subject of cooperatives, the business crisis code provides for the following two changes:

1) in article 2545-terdecies, first paragraph, of the civil code, the second sentence is replaced by the following: "Cooperatives that carry out commercial activities are also subject to judicial liquidation";

2) in article 2545-sexiesdecies, first paragraph, of the civil code, the first sentence is replaced by the following: "Outside the cases referred to in article 2545-septiesdecies, in the event of irregular functioning of the cooperative society, the supervision can revoke the directors and statutory auditors, entrust the management of the company to a commissioner, determining the powers and duration, in order to remedy the irregularities found and, in the event of crisis or insolvency, authorize him to request the appointment of the board or commissioner for the assisted settlement of the crisis itself or access to one of the regulatory procedures provided for in the crisis and insolvency code".

\section{The Organizational and Accounting Structures}

The business crisis code with the introduction of the second paragraph of article 2086 of the civil code has significantly innovated the management of small businesses, bringing them closer to the governance of jointstock companies (see Article 2381 of the Civil Code).

Normally the planning and control process in small businesses is not codified, although it is present; as an entrepreneur, in fact, he does not stop to think about his business and how to organize it, how to improve his profitability, what to do to bring his business into the future.

Therefore, choices and decisions may or may not be formalized through planning and programming systems, but they are present in every organization.

The task of the auditor or mayor, who has an interest in enforcing the new precept of article 2086 of the civil code, is to try, with the flexibility necessary for the structure and size of each company, to bring out the decision-making process and planning and, if possible, to integrate and communicate with the existing accounting and information structures.

It is worth remembering the differences that exist between planning and programming activities: planning moves over medium-long time intervals with the aim of determining the lines of development of the company,

on the contrary programming aims at integrating and putting the strategic lines that have been planned are in place in the short term (usually the year).

Planning means identifying management objectives and the strategies that will allow them to be achieved. Each business planning process, codified in a punctual yet simplified way, consists of various steps and ends with the drafting of a plan, as well as an equity and economic situation that highlight the plan in numbers.

The plan cannot neglect the organizational component and therefore review and adapt the organization chart to the business forecasts and the actions to be carried out. 
In this sense, planning and programming activities constitute a valid support for the management of the company and for the auditor and the mayor they can represent an important anchor to the evolution that top management has thought for the company.

The plans can be of development but also of downsizing or reorganization and therefore they are indispensable even in situations of business crisis.

The importance of control is evident if we address it in its defining aspects and in its most common uses. Management control aims to achieve effectiveness and efficiency in the operations of the company. Let's clarify these concepts better:

- Effectiveness in an economic sense is the ability to achieve set goals, such as improving profitability, increasing market share, restructuring the business, reorganizing the company, improving customer satisfaction.

- Efficiency consists in the wise and rational use of the resources and production factors available, in order to achieve an optimal result

Effectiveness and efficiency are prerogatives that each company pursues but that a valid planning process can optimize, allowing the company to operate at its best to achieve the set goals.

Management control is, therefore, a guarantee for both the administrative body and the control and auditing body.

The need to implement management control systems has significantly increased over time thanks to the increase in the changeability and instability of the markets, increasingly dominated by uncertainty. Evaluating the state of the company, the opportunities and threats that are inherent to its organizational and management model allows each organization to be able to adapt more easily and promptly to changes induced by the external environment.

The obligations established by the Code of the business crisis control of administrative and accounting governance

Controls on organizational and administrative structures are purely the responsibility of the supervisory body, sole auditor or board of statutory auditors, responsible for the prerogatives referred to in Article 2403 and 2477 of the civil code (for spa and srl). The task of the auditors is provided for by articles 2409 bis and 2477 of the civil code.

However, the obligations imposed on the control body and the auditor in terms of alerting introduce a specific new obligation that extends to auditors the controls on organizational and administrative structures; in fact, the law provides that (Article 14):

The corporate control bodies, the auditor and the auditing company, each within the scope of their functions, are obliged to verify that the administrative body constantly evaluates, taking the consequent appropriate initiatives, whether the organizational structure of the company It is appropriate, if there is economic and financial equilibrium and what is the foreseeable trend of management, as well as to immediately report to the same administrative body the existence of well-founded indications of the crisis.

Again, Article 14 of the CCII in the last paragraph introduces a new requirement for credit institutions which will, strangely, concern only the auditors, in particular it is expected that:

The banks and other financial intermediaries referred to in article 106 of the consolidated banking act, when they communicate changes or revisions or revocations of credit lines to the customer, also notify the corporate control bodies, if any.

Controls on organizational structures

Given the provisions of Article 14 of the Crisis Code, both the auditor (or the auditing company) and the statutory auditor (or the board of statutory auditors) must monitor the adequacy of the organizational structure, otherwise taking appropriate initiatives.

The auditor or auditor must, especially in the case of companies that are or could turn towards corporate crises, promptly monitor changes in the organizational structure (dismissals, resignations) and understand whether the change in the composition of the organization chart may be induced by bad conditions. of the work environment or from delays in the payment of fees. 
In the implementation of supervisory tasks, the mayor (and in the opinion of the writer, having regard to the legislation of 2086 of the Italian Civil Code, also the auditor), will have to collect company information and data by carrying out appropriate checks.

He will have to take care to acquire and evaluate the information flows generated by the various bodies and by the different corporate functions present in the Company.

As already partially discussed, with regard to organizational structures, it will be appropriate, as provided for by the rules of conduct of the board of statutory auditors for unlisted companies, to check whether the organizational system adopted by the Company is capable of:

1) identify in a sufficiently clear and precise manner the functions, tasks and lines of responsibility;

2) ensure - through appropriate procedures and concrete operating methods - that the decision-making and directive activity of the Company is effectively exercised by the subjects to whom the relative powers are attributed;

3) provide for and apply procedures that ensure the presence of personnel with adequate competence to perform the functions assigned to them;

4) implement company directives and procedures in order to ensure constant updating of the latter, as well as the effective dissemination of the same among employees.

The adequacy must be assessed according to the complexity of the structure and size of the company, therefore a greater or lesser procedure depending on the type of company.

The criticality for SMEs will concern the fact that the extension of the obligation of adequate organizational structures, previously envisaged for medium-sized companies, could have operational impacts on the performance of the legal control and auditing procedures, given that the company under investigation can equip internal systems immediately or does not have the ideal and competent human resources to whom to entrust internal procedures and controls.

It will be the responsibility of the auditor or mayor to help the entrepreneur to implement human resources and procedures, which, in compliance with the criterion of economy, can allow for organizational adequacy.

A first check will be made on the existence of an organization chart and a function chart (and their updates over time).

The organization chart allows you to prefigure the organizational structure of the Company in its composition. The matrix, functional or divisional structure will have to be verified with interviews to understand if the tasks and functions are outlined, clear and known by the staff.

The mayor or auditor must also verify that company operations are organized on the basis of the "processes" and the sub "procedures".

By processes we mean interdependent activities which, according to a logical and temporal order, are aimed at specific objectives. The procedures describe the rules to be followed in order to do this within the processes pertaining to the activities and to adopt the appropriate decisions for the service and purpose.

At the corporate level, however, it will be appropriate to verify the implementation of the board resolutions regarding delegated powers (signature and representation). The powers of the administrative body must be clear and if there is a collegial body they must be in writing. They must be implemented and communicated in a clear and timely manner. It will be necessary to check the by-laws, the shareholders' meeting and board resolutions relating to the attribution of powers, as well as the powers of attorney issued, verifying them with the results of the Chamber of Commerce records.

If existing, the business plans and their communication, recording and approval by the administrative body will be verified. As well as their communication to the corporate structure, verifying their understanding by human resources and consequent implementation.

The auditor or the statutory auditor will have to check that the business plans are in line with the characteristics of the company and that they are reasonable and achievable. 
The mayor or the auditor, if they find any critical issues in the organizational structure, will have to communicate them to the administrative body and will also have to check, over time, if these criticalities are overcome.

The controls and activities more specifically reserved for the mayor concern:

1) participation in the meetings of the Board of Directors;

2) control over the general performance of management and its foreseeable evolution (in the context of a business crisis, the control over the evolution of management is of particular importance and is linked to checks on financial statement ratios, on the cost-effectiveness of company and on the sustainability of debts in a prospective key);

3) check the possible conflicts of interest of the directors in the transactions carried out;

4) pay attention and give consent (this power also concerns the auditor) to the capitalization of intangible fixed assets and multi-year costs which in times of crisis could hide the desire to reduce operating losses;

5) interact with the supervisory body pursuant to law $231 / 2001$ which must prevent the commission of offenses to verify whether such supervision is active and constant;

6) always in the event of a business crisis, the mayor and the auditor must monitor the operating losses and provide their observations on the financial situation submitted to the assembly which meets upon convocation of the administrative body;

7) as widely and widely anticipated in the previous chapters, statutory auditor and auditor must verify that business continuity is ensured, checking compliance with every quantitative and qualitative element as best practices suggest;

8) check compliance with the regulations in the field of occupational health protection and in general with social security and welfare obligations, given that in conditions of crisis companies could be tempted not to comply with all the practices to guarantee their collaborators and employees;

9) monitor the computer and information system and comply with the procedures regarding the protection and security of sensitive data and personal data in general;

10) verification of adequate care, protection and maintenance of company assets (machinery to produce, capital properties, plants) to understand if the company assets are adequately protected.

11) check that business risks (financial, credit, operational, market, etc.) are known, monitored and covered where possible.

\section{Controls on Administrative and Accounting Structures}

Controls on administrative and accounting structures are a prerogative of both statutory auditors and auditors; after all, the adequacy of the administrative system is a precondition for the reliability of the accounting records and for the preparation and drafting of the financial statements.

In this regard, ISA 315 defines internal control as:

"a process designed, implemented and maintained by those charged with governance, management and other company personnel in order to provide reasonable assurance on the achievement of corporate objectives with regard to the reliability of financial information, effectiveness and efficiency of its operating activities and compliance with applicable laws or regulations. The term "controls" refers to any aspect of one or more components of internal control ".

It is very important to be able to verify whether the business climate is profitable, given that the organization is made up of individuals and their ethical involvement and their responsibility are essential to ensure a common vision and good functionality of the administrative system.

The ISA 350 principle lists the risks that can reduce the operation of a control system, and they can be summarized as follows:

$>$ Integrity and ethical values;

> Shared organization, roles and responsibilities;

$>$ Holdings of the board of directors or executive committee; 
With regard to checks on administrative structures, it is appropriate to refer to Standard 3.6. on the subject of supervision which specifies the following:

"the board of statutory auditors monitors the adequacy of the administrative-accounting structure and its concrete functioning. The administrative-accounting system can be defined as the set of directives, procedures and operating practices aimed at guaranteeing completeness, correctness and timeliness of reliable corporate disclosure, in accordance with the accounting principles adopted by the company. An administrativeaccounting system is adequate if it allows: the complete, timely and reliable accounting recognition and representation of management facts; the production of valid and useful information for the management choices and for the protection of the company assets; the production of reliable data for the preparation of the financial statements ".

The reliability of the data depends on the reliability of the detection system which in turn depends on:

$>$ the preparation and skills of the staff working in the administrative system e

$>$ the resources made available, especially in the IT field.

Supervision must be aimed at verifying that there is a system that is deemed suitable and valid to ensure the integrity and correctness of the economic and equity data as recorded in the accounting.

It is not a question of entering into the economic facts that determined the quantitative surveys, but rather judging how the management event was detected in the administrative and accounting system, deciding on its efficiency and good functioning.

It will be necessary to check promptly whether the company facts are treated according to processes and methods that can lead to a reliable result in a quantitative sense, avoiding that the risks of errors and / or fraud may have been underestimated by the administrative body.

The verification activities on the administrative system are carried out with the sampling method, that is, taking some operations as an example and following them from their entry into the accounting management up to their recording, filing and conservation.

It will be appropriate to check that the tax and corporate regulations are respected, but also and above all that the conservation of physical and IT documents is done in such a way as to guarantee their duration and consultation over time.

In the case of a company that contracts or outsources the administrative and accounting system to an external supplier (traditionally an accountant), the ISA 402 standard dictates some prerogatives and objectives to which the auditor must comply in order to:

a) acquire an understanding of the nature and relevance of the services provided by the supplier and their effect on the internal control of the user company relevant to the audit, which is sufficient to identify and assess the risks of material misstatement;

b) define and carry out audit procedures in response to these risks.

The auditor or the statutory auditor will have to form an opinion on the organizational system of the service provider, in order to understand whether the control objectives, as well as the suitability of the configuration of these controls for the purpose of achieving the audit objectives, are fully guaranteed.

In relation to the rules on the business crisis that will oblige companies to pay attention to the sustainability of debts and business continuity in the short term (six months), the external service provider must ensure adequate and timely reporting of management facts.

The responsibility of the administrative body in terms of preventing the business crisis

Before talking about the responsibility of auditors, it should be remembered that one of the innovations introduced by the CCII is the inclusion of the sixth paragraph in art. 2476 of the Civil Code which establishes the liability of the directors of limited liability companies towards corporate creditors for non-compliance with the obligations inherent in the preservation of the integrity of the corporate assets.

In detail, the new sixth paragraph (introduced by Article 378 of the CCII) reads as follows: 
"The directors are liable to the corporate creditors for non-compliance with the obligations inherent in the preservation of the integrity of the corporate assets. The action can be proposed by the creditors when the corporate assets are insufficient to satisfy their credits. The waiver of the action from part of the company does not prevent the corporate creditors from exercising the action. The transaction can be challenged by the corporate creditors only with the revocatory action when the extremes exist ".

And to qualify the method of determining liability, Article 378 of the CCII always introduces the following paragraph after the second paragraph of Article 2486 of the Civil Code:

"When the liability of the directors pursuant to this article is ascertained, and subject to proof of a different amount, the indemnifiable damage is presumed to be equal to the difference between the shareholders' equity on the date in which the director has left office or, in the event of the opening of an insolvency procedure, on the date of opening of this procedure and the net assets determined on the date in which a cause for dissolution referred to in Article 2484 occurred, less the costs incurred and to be incurred, according to a criterion of normality, after the occurrence of the cause of dissolution and until the completion of the liquidation. If an insolvency procedure has been opened and the accounting records are missing or if due to their irregularity or for other reasons the net assets cannot be determined, the damage It is paid in an amount equal to the difference between assets and liabilities established in the procedure."

The precept enshrined in Article 4 of the CCII, which provides that the debtor has the duty to:

a) explain their situation in a complete, truthful and transparent manner, providing creditors with all the information necessary and appropriate to the chosen instrument for regulating the crisis or insolvency;

b) promptly take suitable initiatives for the rapid definition of the procedure, also in order not to prejudice the rights of creditors;

c) manage the assets or the company during the crisis or insolvency settlement procedure in the priority interest of creditors.

Letter c), as highlighted by many observers and jurists, introduces a rule that is perplexing because in the presence of a crisis (a crisis that could also be a moment of change and turning point) the entrepreneur would find himself having to manage his business and assets in the primary interest of creditors.

This provision contrasts with the spirit of the post-reform regulations dictated by company law and in some way may be a limitation of the rule of autonomy of the administrative body's decisions (the so-called business judgment rule).

In favor of decision-making autonomy, to always remain on the subject of the responsibility of the administrated

It will be appropriate to check that the tax and corporate regulations are respected, but also and above all that the conservation of physical and IT documents is done in such a way as to guarantee their duration and consultation over time.

In the case of a company that contracts or outsources the administrative and accounting system to an external supplier (traditionally an accountant), the ISA 402 standard dictates some prerogatives and objectives to which the auditor must comply in order to:

a) acquire an understanding of the nature and relevance of the services provided by the supplier and their effect on the internal control of the user company relevant to the audit, which is sufficient to identify and assess the risks of material misstatement;

b) define and carry out audit procedures in response to these risks.

The auditor or the statutory auditor will have to form an opinion on the organizational system of the service provider, in order to understand whether the control objectives, as well as the suitability of the configuration of these controls for the purpose of achieving the audit objectives, are fully guaranteed.

\section{The responsibilities of auditors and statutory auditors}

It should be noted that the Business Crisis Code in Article 14 third paragraph establishes an attenuation of the responsibility of the auditor or mayor who promptly report to the administrative body the presence of situations that may lead to the presumption of a state of crisis; the standard establishes that: 
"Timely reporting to the administrative body pursuant to paragraph 1 constitutes a cause for exemption from joint and several liability for the detrimental consequences of the omissions or actions subsequently implemented by the aforementioned body, which are not a direct consequence of decisions taken prior to the reporting, provided that, in the cases envisaged by the second sentence of paragraph 2, a timely report has been made to the OCRI. The report made pursuant to this article does not constitute just cause for revocation from the appointment".

Regarding the responsibility of the supervisory body, it is interesting to mention the decision of the Court of Cassation, sentence no. 21662 of 5 September 2018, with which the Judges ascertain and confirm the responsibility of the statutory auditors for having in particular, in this case relating to a company subsequently bankrupt, failed to exercise their control prerogatives, both in the preventive phase (accounting control and verification of the financial statements) and in the containment phase (complaint to the court) in a situation in which the administrative body had recorded amortization for reduced amounts (without valid reasons) and capitalization of financial charges not directly attributable.

The ruling in some parts comes to argue that:

"The court of merit, after having listed the facts of bad management ascertained by the operating directors and the episodes of non-fulfillment of their duties - in particular relating to the incorrect evaluation of depreciation and fixed assets in the financial statements, operated in violation of accounting principles - stated that they were the consequence of incorrect choices of the administrative body and were made possible by the lack of adequate internal control on the part of the statutory auditors, since, in this way, a progressive impoverishment of the shareholders' equity was caused, to an extent equivalent to the substantial financial resources distributed to the shareholders, such as fictitious operating profits, for the years 1990 and 1991 . As for the mayors, the territorial court notes that they in the reports to the 1991 and 1992 financial statements (the first signed by S. and L., the second S. and P.) denounced an imbalance of the capital and financial structure and the need for reorganization, but they did nothing in reality. to ensure the fulfillment of the management obligation to carry out correct assessments, pursuant to art. $2426 \mathrm{cod}$. civ .: the mayors nevertheless gave a favorable opinion on the 1990 and 1991 financial statements, when the undue posting and distribution of profits only apparently achieved was made. Hence there is a causal link with their omitted control, while the attention of the shareholders' meeting or the public prosecutor was never called for, for the purposes of reporting pursuant to art. 2409 cod. civ."

The statutory auditors and auditors already had in the force of the previous rules (and tomorrow they will have even more, with the entry into force of the business crisis code), the need to act to prevent the crisis by implementing all the behaviors that can the risk of the impoverishment of company assets.

Low depreciation and excessive capitalization of charges are precisely the typical episodes of bad accounting representation, often made in order to contain operating losses; on these grounds and on others still, the control and auditing bodies will have to be confronted to avoid being called to answer with the administrators for fraud or reprehensible negligence.

Paragraph 3 - Business management in the new post-Covid economic context - 19 and the intervention of the legislator

The economic crisis generated by the spread of the coronavirus - Covid 19 disease - has created great difficulties for companies in general and in particular for some sectors, including tourism.

Following the great crisis of 2008, the economic and social context in which companies find themselves operating and paying for the new "normality" has changed, especially small businesses that do not have systems for managing and forecasting future scenarios and who have limited resources to invest in technological and financial capital.

The shock experienced by the world economy following the spread of Covid - 19 has further weakened the economy by creating the ground for possible shocks and financial tensions.

The legislation of the Italian legislator to reduce bankruptcies and facilitate business continuity during the period of spread of COVID - 19

To address the emergency resulting from the spread of the coronavirus, direct measures have been adopted that seek to prevent the expansion of the negative and recessive effects on the economic system. These are 
emergency measures issued to support work and businesses. The first regulations, such as Legislative Decree $18 / 2020$, tried to give companies liquidity.

Various measures to suspend compliance and tax payments were initially introduced for the areas and sectors most affected and then extended to the entire national territory.

Rules have been introduced that have mitigated the burden of tax advances and paid in installments of social security and tax contributions, trying to mitigate the tax impact on companies in difficulty that had seen their turnover fall beyond certain thresholds.

On other fronts, for example, the legislator intervened by providing for grants for expenses. To reduce the burden of leasing charges and also to mitigate the costs for sanitizing work environments.

Many interventions with the methodology of the rain intervention, which contributed in a not always efficient way to mitigate the stranglehold of the crisis and which in some cases was not directed to companies in difficulty but to all companies, such as the supply of the first redundancy fund measures aimed at all companies.

So, the interventions went on three fronts:

$>$ Liquidity support,

$>$ Tax and social security benefits,

Ditigation of obligations in the field of bankruptcy procedures and on business crisis.

On liquidity support, the decrees introduced rules that facilitated both the granting of loans and the suspension of loan plans in progress.

The tax and social security benefits were numerous and involved the granting of deferrals, postponement of deadlines, installments of taxes and contributions, granting of non-repayable grants and interventions to guarantee layoffs.

The other types of interventions were aimed at encouraging internationalization and the relaxation of bankruptcy rules. Other measures have protected the business continuity, in the balance sheet evaluations, and others have taken care to favor recapitalization.

In this paper we will try to focus on the measures that have turned their attention to the rules on bankruptcy and business crisis.

The capital strengthening measures of the companies took the form of tax credit granted to those who made investments in Italian companies that suffered a reduction in revenues from the coronavirus.

In addition, a fund has been set up to support the Italian production system, called Fondo Patrimonio PMI, which has the purpose of underwriting newly issued bonds issued by medium-sized companies affected by the economic crisis.

Cassa Depositi e Prestiti has also been placed in a position to set up a designated patrimony, made up of funds contributed by the Ministry of Economy and Finance, which will be able to support and relaunch the Italian economic system.

The Minister of Economy and Finance was authorized to subscribe to capital increases, or capitalization instruments, of state-controlled companies.

On the issue of capital strengthening, the decree law of August 2020 must also be considered, which refinanced the law defined as Nuova Sabatini which allows SMEs to be granted subsidized loans for investments in new capital goods.

To protect the production system, the D.L. n. 34/2020 established a Fund for the safeguarding of employment at the Ministry of Economic Development which allows the State to intervene in order to guarantee the continuation of the business activity, saving the companies that own historical brands of national interest and joint-stock companies, with no less than 250 employees in a state of economic difficulty.

Subsequently the D.L. 104/2020 refinanced and extended the scope of intervention of the aforementioned Fund allowing it to intervene for the rescue of companies which, regardless of the number of employees, hold assets and relationships of strategic importance for the national interest. 
In terms of bankruptcy and business crisis regulations, art. 5 of the D.L. $23 / 2020$ postponed to 1.9 .2021 the entry into force of the business crisis code initially provided for by Legislative Decree 12.1.2019, $\mathrm{n}$. 14, for 15.8.2020.

This deferral was carried out to avoid that the alert regulations could generate reports and the consequent start of pre-bankruptcy procedures to the detriment of companies that, due to Covid - 19, have seen their economic fundamentals deteriorate.

Still on the subject of bankruptcy, art. 10 of the Liquidity Decree 23/2020 provided for the non-prosecution of appeals aimed at declaring bankruptcy and the state of insolvency of companies in crisis. The inadmissibility concerned the applications filed in the period between 9.3.2020 and 30.6.2020. This was a provision of an exceptional and transitory nature due to the emergence of crises caused by extraordinary factors and not attributable to companies due to the pandemic crisis.

For bankruptcy deflation procedures, art. 9 of the D.L. 23/2020 a favorable rule addressed to companies that had started restructuring processes on the basis of an arrangement with creditors or a debt restructuring agreement and whose execution terms could have suffered damage due to the spread of the economic crisis caused by COVID-19. The most important measure concerned the 6-month extension of the deadlines for fulfilling the arrangements with creditors and restructuring agreements which had been approved and which had a deadline between 23.2.2020 and 31.12.2021.

The legislator also intervened in favor of companies to ensure business continuity and the reduction of capital due to losses incurred during 2020.

In particular, provision was made for the temporary suspension of the provisions which provide for particular procedures in the event of a reduction in capital due to a loss; another rule has stability of the exceptions regarding the deferral of shareholder loans, we see in detail below.

Art. 6 of the D.L. 23/2020 has established that, with effect from 9.4.2020 and until 31.12.2020, the provisions of the civil code regarding the reduction of share capital following losses incurred will not apply.

More specifically, the rule provides for an exception to Articles 2446, paragraphs 2 and 3, 2447, 2482, paragraphs 4, 5 and 6, and 2482-ter of the Italian Civil Code

Still in the period scheduled from 9 April to the end of the year, the cause of dissolution of the company due to reduction or loss of the share capital referred to in Articles 2484, paragraph 1, n. 4), and 2545-duodecies of the Italian Civil Code

The derogation from the application of the rules on the reduction of share capital is not new since similar provisions are provided, for example, in art. 182-sexies (on the basis of which the rules on the reduction of share capital do not apply from the date of filing of the application for admission to the composition with creditors, also pursuant to article 161 sixth paragraph, of the application for the approval of restructuring agreement referred to in Article 182-bis or the proposed agreement pursuant to the sixth paragraph of the same article and up to approval), the wording of which is exactly the same as that in question.

This deferral was carried out to avoid that the alert regulations could generate reports and the consequent start of pre-bankruptcy procedures to the detriment of companies that, due to Covid - 19, have seen their economic fundamentals deteriorate.

Still on the subject of bankruptcy, art. 10 of the Liquidity Decree 23/2020 provided for the non-prosecution of appeals aimed at declaring bankruptcy and the state of insolvency of companies in crisis. The inadmissibility concerned the applications filed in the period between 9.3.2020 and 30.6.2020. This was a provision of an exceptional and transitory nature due to the emergence of crises caused by extraordinary factors and not attributable to companies due to the pandemic crisis.

For bankruptcy deflation procedures, art. 9 of the D.L. 23/2020 a favorable rule addressed to companies that had started restructuring processes on the basis of an arrangement with creditors or a debt restructuring agreement and whose execution terms could have suffered damage due to the spread of the economic crisis caused by COVID-19. The most important measure concerned the 6-month extension of the deadlines for fulfilling the arrangements with creditors and restructuring agreements which had been approved and which had a deadline between 23.2.2020 and 31.12.2021. 
Financial Markets, Institutions and Risks, Volume 4, Issue 4, 2020 ISSN (online) - 2521-1242 ISSN (print) - 2521-1250

The legislator also intervened in favor of companies to ensure business continuity and the reduction of capital due to losses incurred during 2020.

In particular, provision was made for the temporary suspension of the provisions which provide for particular procedures in the event of a reduction in capital due to a loss; another rule has stability of the exceptions regarding the deferral of shareholder loans, we see in detail below.

Art. 6 of the D.L. 23/2020 has established that, with effect from 9.4.2020 and until 31.12.2020, the provisions of the civil code regarding the reduction of share capital following losses incurred will not apply.

More specifically, the rule provides for an exception to Articles 2446, paragraphs 2 and 3, 2447, 2482, paragraphs 4, 5 and 6, and 2482-ter of the Italian Civil Code

Still in the period scheduled from 9 April to the end of the year, the cause of dissolution of the company due to reduction or loss of the share capital referred to in Articles 2484, paragraph 1, n. 4), and 2545-duodecies of the Italian Civil Code

The derogation from the application of the rules on the reduction of share capital is not new since similar provisions are provided, for example, in art. 182-sexies (on the basis of which the rules on the reduction of share capital do not apply from the date of filing of the application for admission to the composition with creditors, also pursuant to article 161 sixth paragraph, of the application for the approval of restructuring agreement referred to in Article 182-bis or the proposed agreement pursuant to the sixth paragraph of the same article and up to approval), the wording of which is exactly the same as that in question.

However, the directors will not be able to easily repay the loans granted during the period of economic emergency due to the pandemic. They will have to carefully evaluate the equity and economic condition of the company in order to be able to repay or start debt amortization plans, this is to avoid that an accelerated or early repayment of shareholder loans can cause financial stress that can lead to insolvency. economic / financial aspects of the company: this conduct, while not expressly violating the provisions of Articles 2467 and 2497quinquies of the Italian Civil Code, could indeed assume relevance under various liability profiles in the event of worsening of the financial situation of the company and consequent submission to insolvency proceedings.

The rule tends to equate the legal position of the financing partner to that of third-party financiers. The impact of this legislation must be considered favorably because it will tend to facilitate the shareholders who have the resources to favor the inflow of liquidity into their businesses, thus increasing the probability of the business survival.

The legislator introduced with Article 26 of the D.L. 34/2020 a further provision aimed at favoring the capitalization of companies thanks to the capital increases made by the shareholders. The forecast facilitates both the transferring shareholder and the company receiving the capital injection.

The measure is aimed only at companies that have had a reduction in their revenues due to the coronavirus; the reduction in revenues is measured by comparing the period of closure due to lockdown with the corresponding period of 2019 and the reduction in revenues must be greater than $33 \%$. The measure is aimed at small and medium-sized enterprises since there is an application limit that will only concern companies with revenues between 5 and fifty million euros.

The paid capital increases approved after 19/5/2020, with the payment made by 31 December of the same year, will give the shareholder the right to a $20 \%$ tax credit to be calculated on the amount of the contribution made.

The provision provides for a limit on contributions; the tax credit will be calculated within the maximum limit of two million euros of contributions.

A difficult calculation mechanism provides for a tax credit also in favor of the company that received the contribution to the share capital account, or share premium reserve; it is envisaged that the company will have in the financial statements relating to 2020 , a tax credit equal to $50 \%$ of the losses that exceed $10 \%$ of the net assets, gross of the losses themselves, and in any case up to $30 \%$ of the increase in capital carried out.

The regulations that have followed one another and which are likely to follow one another in the coming months highlight the concern that the Italian legislator has had in preparing rules that can allow companies, affected by the economic crisis caused by the pandemic, to maintain or recover business continuity and management and at the same time being able to recapitalize. 


\section{Conclusions}

The Italian legislation on the business crisis, which largely anticipates the EU legislation of 2019, provides for modern mechanisms which, by acting on the organization and governance of companies, make it possible to anticipate the emergence of the business crisis, avoiding bankruptcy and improving the market functioning mechanism.

These regulations tend to preserve production capacity and employment and reduce the possibility of creating non-performing loans that would somehow adversely affect banks' balance sheets.

A Bank of Italy study demonstrates how insolvency can be avoided if companies anticipate the emergence of the business crisis by adhering to bankruptcy deflation procedures such as debt restructuring agreements and arrangement with creditors. Failing to understand the signs of the business crisis, perhaps thanks to inadequate governance systems, can lead companies to bankruptcy.

The economic crisis due to the pandemic is the umpteenth of many economic crises that since 11 September 2001, and even earlier with the dot.com crisis, have changed the world economic context, creating a strong variability of macroeconomic fundamentals. In this more uncertain context, companies find themselves having to create and manage modern mechanisms for forecasting external criticalities capable of stabilizing their business model avoiding financial tensions and bankruptcies. The crises of recent decades and the recent stalemate generated by the spread of the coronavirus clearly confirm that the management of the company is ontologically subject to risk and that to mitigate the latter and guarantee continuity, a constant and profound, more or less articulated, companies need to strengthen their administrative and accounting governance. There is no other way to prevent the crisis than by making an effort to look at what is happening and what may happen soon. During the pandemic, the Italian government introduced, sometimes in a confused and dispersed way, many regulations to try to allow companies to maintain business continuity while avoiding bankruptcy; these rules have often derogated from current legislative provisions that would have started many companies towards insolvency. Time will tell if the interventions have been sufficient, the companies on their part will have to keep a strong focus on external events by improving their organizational structures as required by the new article 2086 of the civil code.

\section{References}

1. Alrabba, H. M. (2016). Measuring the impact of code of ethics on the quality of auditors' professional judgment. Journal of Governance and Regulation, 5(4), 54-60. https://doi.org/10.22495/jgr_v5_i4_p4

2. Brewster, D. (2004, August 9). CalPERS wave-making brings flak. Financial Times Fund Management. Retrieved from: https://www.ft.com/fund-management

3. Butz, C. (2003). Decomposing SRI Performance, Geneva: Pictet \& Cie. Retrieved from: https://scholar.google.com/scholar_lookup?title=Decomposing\%20SRI\%20performance\&author=C.\%20But z\&publication_year $=2003$

4. Cadbury Committee (1992). Report of the Committee on the Financial Aspects of Corporate Governance. Retrieved from: http://www.ecgi.org/ codes/documents/cadbury.pdf

5. Collins, J. (2001). Good to great. London: Random House Business. Retrieved from: https:/www.penguin.co.uk/books/104/1045846/good-to-great/9780712676090.html

6. Collins, J., \& Porras, J. (1994). Built to last. New York: Harper Business. Retrieved from: https://www.amazon.com/Built-Last-Successful-Visionary- Essentials/dp/0060516402

7. Conference Board (2003). Commission on public trust and private enterprise: Findings and recommendations. Retrieved from: https://www.conference- board.org/pdf_free/SR-03-04-ES.pdf

8. Doyle, J. L., Colley, J., Stettinius, W., \& Logan, G. (2005). What Is Corporate Governance? New York: McGraw-Hill. Retrieved from: https://trove.nla.gov.au/version/20047751

9. El Nashar, T. (2016). The probable effect of integrated reporting on audit quality. Journal of Governance and Regulation, 5(2), 50-58. http://doi.org/ 10.22495/jgr_v5_i2_p6 
10. Eun, C. S., Resnick, B. G., \& Sabherwal, S. (2004). International Finance. Wall Street Journal. Aril 9, 1996. Retrieved from: https://link.springer.com/content/pdf/bbm\%3A978-3-030-02792-6\%2F1.pdf

11. Ferri Di Fabrizio, L. (2017). The pattern of fraudulent accounting: Ethics, external auditing and internal whistle-blowing process. Journal of Governance and Regulation, 6(1), 12-25. http://doi.org/10.22495/jgr v6 i1 p2

12. Feten, A., \& Salma, D.-A. (2015). The use of international standards in ethics education in the Tunisian audit context. Journal of Governance and Regulation, 4(4-4), 499-506. http://doi.org/10.22495/jgr_v4_i4_c4_p7

13. Gimbel, F. (2004, April 19). US activist launches hedge fund (for corporate governance). FT Fund Management. Retrieved from: http://nylawyer.nylj.com/adgifs/decisions/120607hedgefund1.pdf

14. Gompers, P., Ishii, J., \& Metrick, A. (2001). Corporate governance and equity prices (NBER Working Paper No. 8449). Retrieved from: https://www.nber.org/system/files/working_papers/w8449/w8449.pdf

15. Habbash, M. (2012). Earnings management, audit committee effectiveness and the role of blockholders ownership: Evidence from UK large firms. Journal of Governance and Regulation, 1(4-1), 100116. http://doi.org/ 10.22495/jgr_v1_i4_c1_p1

16. ICGN (2002). Cross border proxy voting, case studies from the 2002 proxy voting season.London: International Corporate Governance Network. Retrieved from: https://www.icgn.org/policy /viewpoints/cross-border-voting.

17. IF AC (2003). Rebuilding public confidence in financial reporting: An international perspective. New York: International Federation of Accountants. Retrieved from: https://www.ifac.org/knowledgegateway/contributing-global-economy/publications/rebuilding-public-confidence-financial-reportinginternational-perspective

18. IFAC (2004). Enterprise governance: Getting the balance right. New York: International Federation of Accountants. Retrieved from: https://www.ifac.org/about-ifac/professional-accountantsbusiness/publications/enterprise-governance-getting-balance-right-2

19. Kandemir, H. K. (2016). Auditing versus consultancy: a critique of the EU law reforms on the new form of auditing. Journal of Governance and Regulation, 5(3), 90-97. http://doi.org/10.22495/jgr_v5 i3 p8

20. Krauß, P., \& Zülch, H. (2013). The relation of auditor tenure to audit quality: Empirical evidence from the German audit market. Journal of Governance and Regulation, 2(3), 27-43. http://doi.org/10.22495/jgr_v2 i3 p2

21. Larcker, D., Richardson, S., \& Tuna, I. (2005, May 2). Ratings add fire to the governance debate. FT Mastering Corporate Governance https://aaapubs.org/doi/pdf/10.2308/accr.2007.82.4.963

22. Ledimo, O., \& Martins, N. (2014). An audit of employee commitment to enable leaders to manage organizational talent. Journal of Governance and Regulation, 3(3-1), 128-133. http://doi.org/10.22495/jgr_v3 i3_c1_p6

23. Los Angeles Times (2004, April 3). Ex-exec tells of Adelphia fraud. Retrieved from: https://www.jstor.org/stable/29789727?seq=1\#page scan tab contents

24. McKinsey \& Company (2002). Global investor opinion survey on corporate governance, London, McKinsey \& Company.Standard \& Poor's Governance Services (2002). Corporate Governance Scores: Criteria, Methodology and Definitions, New York, Standard and Poor's. Retrieved from: https://www.mckinsey.com/client service/corporate finance/latest thinking/mckinsey_on finance/ /media/ DD152F22B7CC4B099913E114AC5558FB.ashx

25. Monks, R. A. G., \& Minow, N. (2015). Corporate Governance (5thed.). Chichester, The UK: John Wiley \& Sons Ltd. http://doi.org/10.1002/ 9781119207238

26. Murase, H., Numata, S., \& Takeda, F. (2013). [Conference issue]. Journal of Governance and Regulation, 2(3), 7-23. http://doi.org/10.22495/jgr_v2_i3_p1 
27. Special report: corporate governance, investors fight back. (2004, May17). Business Week. Retrieved from: https://www.sec.gov/Archives/edgar/data/1018724/000119312516530747/d78603ddef14a.htm

28. Tayan, B. \& Larcker, D. F. (2015). Corporate governance matters: A closer look at organizational choices (2nd ed.). New Jersey: Pearson Education. Retrieved from: https://www.amazon.com/CorporateGovernance-Matters- Organizational-Consequences/dp/0134031563

29. Tricker, P. I. (2017). Corporate governance: principles, policies, and practices. Oxford, the UK: Oxford University Press. Retrieved from: https://global.oup.com/ukhe/product/corporate-governance9780198702757? cc=ua\&lang=en\& 